\title{
Liming and Phosphating on growth, nutritional status and mycorrhizal colonization of
}

\section{yellow strawberry guava}

\author{
Jorge Atílio Benati ${ }^{1 *} \odot$, Renan Navroski1 ${ }^{1}$, Caroline Farias Barreto ${ }^{1}$, Lucas de Oliveira Fischer ${ }^{1} \odot$, Gilberto Nava ${ }^{2} \odot$, Rodrigo Cezar \\ Franzon ${ }^{2} \odot$, Flavio Gilberto Herter ${ }^{1}$, Murilo Dalla Costa ${ }^{3}$
}

\author{
'Universidade Federal de Pelotas/FAEM - Depto. de \\ Fitotecnia, Av. Eliseu Maciel, s/n -96010-610 - Capão do \\ Leão, RS - Brasil. \\ 2Embrapa Clima Temperado, BR 392, km 78 - 96010-971 - \\ Pelotas, RS - Brasil. \\ ${ }^{3}$ Empresa de Pesquisa Agropecuária e Extensão Rural de \\ Santa Catarina, R. José Godinho, s/n - 88502-970 - Lages, \\ SC - Brasil. \\ ${ }^{*}$ Corresponding author <jorgeatiliobenati@hotmail.com>
}

Edited by: Anoop Kumar Srivastava

Received March 10, 2021

Accepted June 03, 2021
ABSTRACT: Strawberry guava (Psidium cattleyanumm Sabine) is a species native to southern Brazil which exhibits significant potential for economic exploitation. The objective of this study was to evaluate the growth response of strawberry guava subjected to liming and phosphate fertilizer in pre-planting. The treatments consisted of four lime levels: 0; 33.3; 66.6 and $100 \%$ of the dose needed to increase the $\mathrm{pH}$ in water to 6.0 , and four phosphorus (P) doses: 0 ; 83.3; 166.6 and $250 \mathrm{~kg} \mathrm{ha}^{-1}$ of $\mathrm{P}_{2} \mathrm{O}_{5}$. Plant growth parameters were evaluated for three years. In the years 2018 and 2019, the mineral composition of leaves, photosynthethic pigment indices and mycorrhizal colonization on strawberry guava roots were measured. Liming and phosphate fertilizer altered neither plant growth nor the photosynthetic pigment indices and there was no interaction between the factors studied and the remaining variables evaluated. However, liming promoted increases in the $\mathrm{Ca}$ and $\mathrm{Mg}$ shoot content, and the phosphate fertilizer increased the levels of shoot $P$ in the third year of growth. Mycorrhizal colonization was stronger when the $P$ soil levels were low, which could explain the absence of response to phosphate fertilization on plant growth for the first three years after planting.

Keywords: Psidium cattleyanum Sabine, fertility, limestone, phosphorus, soil acidity

\section{Introduction}

Strawberry guava (Psidium cattleyanum Sabine) is a native plant from the Atlantic coast of Brazil which has adapted to tropical climates such as Hawaii and many Caribbean Islands (Patel, 2012). For some years, it has been considered one of the native fruit species from southern Brazil with high nutraceutic and pharmaceutic properties (Medina et al., 2011; Ribeiro et al., 2014), since its fruit presents high contents of phenolic and antioxidant compounds, together with its suitability to in natura consumption (Denardin et al., 2015).

In Brazil, the soils where strawberry guava occurs naturally present, in general, high acidity $(\mathrm{pH}<5.0)$. In this condition, there is limitation on the availability of nutrients such as $\mathrm{P}, \mathrm{Ca}$ and $\mathrm{Mg}$ for root uptake. Furthermore, $\mathrm{Al}$ and $\mathrm{Mn}$ concentrations reach toxic levels in the plants (Qaswar et al., 2020). However, plant growth in acid soils indicates adaptation and presence of strategies for nutrient uptake under low availability as seen with low P supply.

Strawberry guava is capable of forming mycorrhizal associations of the arbuscular type in the root system (Wang and Qiu, 2006); This symbiosis can increase the nutrient uptake, $\mathrm{P}$ in certain cases, and water through the fungal hypha (Smith and Read, 2010). In exchange for photosynthates, usable as an energy source for the formation, maintenance and functioning of mycorrhizal structures, the arbuscular mycorrhizal fungi hypha can provide up to $80 \%$ of $\mathrm{P}, 25 \%$ of nitrogen, $10 \%$ of potassium, $25 \%$ of zinc and $60 \%$ of copper to the plant metabolism (Marschner and Dell, 1994; Gianinazzi et al., 2010). However, strawberry guava's yield potential may still not be expressed under natural soil $\mathrm{pH}$ conditions, similar to what has been observed in other fruit species which, in acid soils, present slower growth and low yield (Nava et al., 2016). To correct this, lime should be applied to increase the soil $\mathrm{pH}$ up to 6.0 for the majority of species (CQFS/RS-SC, 2016). The acidity correction increases $\mathrm{P}$ availability to the plant metabolism by translocating orthophosphate ions from the aluminum and iron oxide surfaces or from clay minerals to the soil solution (Ernani, 2016; Qaswar et al., 2020).

Due to the scarcity of research studies in the area of strawberry guava nutrition, currently lime and fertilization similar to the ones used for other native fruit species such as the feijoa (Acca sellowiana) are suggested. Thus, a definition of adequate fertilizer levels for the strawberry guava crop is required in order to allow better seedling growth, yield and fruit quality. Given this context, this work aimed to evaluate the interaction of liming with phosphate fertilizer in preplanting in the soil chemical parameters, as well as in growth, nutrition and mycorrhizal colonization in yellow strawberry guava plants.

\section{Materials and Methods}

\section{Description of experiment and soil characterization}

The work was performed in Pelotas, Rio Grande do Sul, Brazil $\left(31^{\circ} 40^{\prime} 47^{\prime \prime} \mathrm{S}, 52^{\circ} 26^{\prime} 24^{\prime \prime} \mathrm{W}\right.$, altitude of $\left.60 \mathrm{~m}\right)$. The climate in this region, according to W. Köppen is subtropical humid (Cfa), or temperate humid with hot summers (Alvares et al., 2013). 
The orchard was installed in Dec 2016, with yellow strawberry guava plantlets from "selection 118", originating from seeds collected from a single matrix plant in Mar. 2016. After germination, the plantlets were transferred to $0.8 \mathrm{~L}$ pots containing commercial Sphagnum peat substrate and maintained in a greenhouse until the orchard had been planted. The soil was classified as Ultisols (Red-yellow Argisol according to the Brazilian classification and Acrisols according to the WRB classification) (Soil Survey Staff, 2014). Before setting up the experiment, soil physico-chemical analyses were completed, showing the following results: $\mathrm{pH}$ in water of 4.5 (1:1 ratio); 4.4 and $21 \mathrm{mg} \mathrm{kg}^{-1} \mathrm{P}$ and $\mathrm{K}$, respectively (extracted by Mehlich-1); $0.6 \mathrm{cmol}_{\mathrm{c}} \mathrm{kg}^{-1}$ $\mathrm{Ca} ; 0.1 \mathrm{cmol}_{\mathrm{c}} \mathrm{kg}^{-1} \mathrm{Mg}$; $0.3 \mathrm{cmol}_{\mathrm{c}} \mathrm{kg}^{-1} \mathrm{Al}$ (extracted by $\mathrm{KCl} 1.0 \mathrm{~mol} \mathrm{~L}^{-1}$ ); $9.0 \mathrm{~g} \mathrm{~kg}^{-1}$ organic matter - WalleyBlack Method; $140 \mathrm{~g} \mathrm{~kg}^{-1}$ clay; cation exchange capacity $\left(\mathrm{CEC}_{\mathrm{pH} 7.0}\right) 3.6 \mathrm{cmol}_{\mathrm{c}} \mathrm{kg}^{-1}$; aluminum (27.3\%) and base $(22 \%)$ saturation.

The treatments were arranged in a split-plot design, in a random block design with three replications. The experimental plots were composed of six $51.2 \mathrm{~m}$ long lines with $4.6 \mathrm{~m}$ spacing, where each block was composed of two lines. The treatments allocated in the main plots $(12.8$ $\times 4.0 \mathrm{~m}$ ), were the four lime levels: $0 ; 33.3 ; 66.6$ and $100 \%$ of the dose needed to elevate $\mathrm{pH}$ in water up to 6.0 (corresponding doses of $1.5 ; 3.0$ and $4.5 \mathrm{Mg} \mathrm{ha}^{-1}$ of lime, respectively). The lime used was a dolomitic type with $60 \%$ effective calcium carbonate (ECC). In the sub-plots $(6.4 \times 2.0 \mathrm{~m})$, four P doses were applied: 83.3; 166.6 and $250 \mathrm{~kg} \mathrm{ha}^{-1} \mathrm{P}_{2} \mathrm{O}_{5}$ - which correspond to 33; 66 and $100 \%$ of the dose for increasing $\mathrm{P}$ availability to the critical level (CQFS-RS/SC, 2016). Each sub-plot was composed of four plants, the central two being considered the useful plot area. After planting, all the plants were pruned at a height of $45 \mathrm{~cm}$.

Lime and $\mathrm{P}$ doses were applied during the area set up only in the planted strip ( $2 \mathrm{~m}$ wide) and were incorporated in the soil through a sequence of plowing and harrowing up to $20 \mathrm{~cm}$ deep. Ninety $\mathrm{kg} \mathrm{ha}^{-1} \mathrm{~K}$ was applied to the plots in accordance with fruit science guidelines (CQFS - RS/SC, 2016). After planting, $40 \mathrm{~kg}$ $\mathrm{ha}^{-1} \mathrm{~N}$ were applied as urea, split in three applications every 45 days, starting at the beginning of spring.

\section{Nutrient content in leaves and in the soil}

In order to determine the macronutrient leaf content (N, P, K, Ca and Mg), in Mar 2018 and 2019, 40 leaves were collected from the median portion of branches less than a year old located halfway up the plant. Leaves were dried in an oven at $65{ }^{\circ} \mathrm{C}$, until constant mass, and then grounded. Sub-samples of $0.5 \mathrm{~g}$ were subjected to nitro-perchloric acid digestion with $\mathrm{HClO}_{4}(1.0$ $\mathrm{mL})+\mathrm{HNO}_{3}(6.0 \mathrm{~mL})$ at $190{ }^{\circ} \mathrm{C}$, in a digestion block (Tedesco et al., 1995). In the extract, $\mathrm{P}$ concentrations were determined by UV spectrophotometer (vanadatemolybdate method) and $\mathrm{K}, \mathrm{Ca}$ and $\mathrm{Mg}$ by flame atomic absorption spectrometry (Tedesco et al., 1995). N was determined by the combustion method in a TruSpec CHN-S elemental analyzer, in which $\mathrm{N}$ is quantified with the aid of a thermal conducing cell and the results are expressed as a percentage of $\mathrm{N}$. At the time of the leaf sampling, soil samples were taken at a depth of $0-20 \mathrm{~cm}$ soil for physico-chemical analysis (Tedesco et al., 1995).

\section{Photosynthetic pigment index}

In Mar of 2018 and 2019, the chlorophyll (CI), flavonoid (FI) and nitrogen balance indices (NBI) were evaluated in a portable chlorophyll meter. The measurement was taken from the median part of the leaf, in ten leaves from each sub-plot, between 8 and 11 a.m. avoiding readings of the central veins. One reading was taken per leaf, and the mean values were then calculated (sub-plot mean).

\section{Plant growth parameters}

In Aug 2017, 2018 and 2019, the following plant growth parameters were evaluated: trunk perimeter $(\mathrm{mm})$, plant height $(\mathrm{cm})$ and canopy volume $\left(\mathrm{m}^{3}\right)$, according to the equations:

Perimeter $=$ diameter $\times \varpi$;

Canopy volume $=$ Canopy height $\times$ Canopy transverse width $\times$ canopy longitudinal width

\section{Mycorrhizal colonization}

In Oct 2018, root samples were collected, composed of approximately $1.0 \mathrm{~g}$ of root fragments randomly picked from the area under the projection of the canopy. The samples were conserved in $50 \%$ alcohol for an analysis of colonization frequency, mycorrhizal colonization rate and arbuscule content in the mycorrhized root fractions. The roots were washed in tap water and subjected to bleaching with $10 \% \mathrm{KOH}$ for $30 \mathrm{~min}$ at $121{ }^{\circ} \mathrm{C}$ (Koske and Gemma, 1989), followed by washing in running water and $10 \% \mathrm{H}_{2} \mathrm{O}_{2}$ for $35 \mathrm{~min}$ at room temperature. After washing in water, the root samples remained in an acid solution (5\% glacial acetic acid) for $2 \mathrm{~h}$. After this phase, bleached roots were stained with $5 \%$ black ink (Shaefer) diluted in $5 \%$ glacial acetic acid for 5 min at $90{ }^{\circ} \mathrm{C}$ (Vierheilig et al., 1998). Excess stain was removed through rinsing with water and the samples stored in distilled water until slides for microscopic evaluation were prepared. The frequency and intensity of mycorrhizal colonization and arbuscule content in the mycorrhized fraction were analyzed in 20 root fragments per replication.

\section{Statistical analyses}

The data were checked for normal distribution fitting with the Shapiro Wilk's test and subjected to analysis 
of variance (ANOVA), and where significant $(F \leq 0.05)$, the average means were fitted to polynomial regressions to determine the effects of lime and $\mathrm{P}$ doses, as well as the possible interactions between these factors. The statistical analyses were performed with the aid of the Sisvar software program, v. 5.6 (Ferreira, 2014).

\section{Results}

\section{Soil and leaf nutrient concentration}

Independent from the soil chemistry parameters analyzed, there was no interaction between the lime and $\mathrm{P}$ doses applied. However, the $\mathrm{Ca}$ and the $\mathrm{Mg}$ in the soil were positively influenced by the addition of lime, and both presented a linear increase. $\mathrm{K}$ content in the soil was not altered by either the lime or the $\mathrm{P}$ levels (Tables 1 and 2). The lime elevated $\mathrm{pH}$ values and neutralized exchangeable $\mathrm{Al}$ without affecting soil OM (Tables 3 and 4).

For the phosphate fertilizer, in the years 2018 and 2019 , the $\mathrm{P}$ available in the $0-20 \mathrm{~cm}$ soil layer increased linearly according to the $\mathrm{P}$ doses used (Table 2). Thus, the highest $\mathrm{P}$ dose $\left(250 \mathrm{~kg} \mathrm{P}_{2} \mathrm{O}_{5} \mathrm{ha}^{-1}\right)$, raised the available $\mathrm{P}$ to values above $30 \mathrm{mg} \mathrm{P} \mathrm{O}_{5} \mathrm{~kg}^{-1}$, which is considered a high content for the soil studied (CQFS-RS/SC, 2016). In the second year, there was a reduction in the available $\mathrm{P}$ levels, however, following a linear fitting in response to $\mathrm{P}_{2} \mathrm{O}_{5}$ applied to the soil.

In 2018, leaf nutrient concentrations showed no interaction between applied lime and $\mathrm{P}$ doses. $\mathrm{Ca}$ and $\mathrm{Mg}$ leaf contents fitted significantly to the linear regression model increasing as a function of the lime doses (Table 5). In the second year of evaluation, $\mathrm{K}$

Table 1 - Soil levels of $\mathrm{K}, \mathrm{P}, \mathrm{Ca}$ and $\mathrm{Mg}$ available in response to the application of increasing doses of lime to the soil in 2018 and 2019 .

\begin{tabular}{|c|c|c|c|c|}
\hline Lime dose & \multicolumn{4}{|c|}{ Nutrient content available in the soil $\left(\mathrm{mg} \mathrm{kg}^{-1}\right)$} \\
\hline $\mathrm{Mg} \mathrm{ha}^{-1}$ & \multicolumn{2}{|c|}{$\mathrm{mg} \mathrm{kg}^{-1}$} & \multicolumn{2}{|c|}{$\mathrm{cmol}_{\mathrm{c}} \mathrm{kg}^{-1}$} \\
\hline \multicolumn{5}{|c|}{2018} \\
\hline & K & $P$ & $\mathrm{Ca}$ & $\mathrm{Mg}$ \\
\hline 0 & $51.41^{\mathrm{ns}}$ & $27.00^{\text {ns }}$ & $1.10^{* 1}$ & $0.70 * 2$ \\
\hline 1.5 & 48.08 & 19.31 & 1.55 & 0.89 \\
\hline 3.0 & 46.16 & 19.99 & 2.01 & 1.16 \\
\hline 4.5 & 53.41 & 21.85 & 2.36 & 1.29 \\
\hline CV (\%) & 15.70 & 26.25 & 24.62 & 22.59 \\
\hline \multicolumn{5}{|c|}{2019} \\
\hline & K & $\mathrm{P}$ & $\mathrm{Ca}$ & $\mathrm{Mg}$ \\
\hline 0 & $28.75^{\text {ns }}$ & $11.80^{\text {ns }}$ & $0.70 * 3$ & $0.70 * 4$ \\
\hline 1.5 & 24.58 & 7.79 & 1.05 & 0.89 \\
\hline 3.0 & 26.91 & 8.03 & 1.30 & 1.10 \\
\hline 4.5 & 30.08 & 10.11 & 1.58 & 1.20 \\
\hline CV (\%) & 28.05 & 53.71 & 18.71 & 29.30 \\
\hline
\end{tabular}

${ }^{1} y=0.2827 x+1.119\left(R^{2}=0.9964\right) ;{ }^{2} y=0.136 x+0.704\left(R^{2}=0.9843\right) ;{ }^{3} y$ $=0.1927 x+0.724\left(R^{2}=0.9951\right) ; 4 y=0.114 x+0.716\left(R^{2}=0.9807\right) ; C V=$ coefficient of variation; * Significant $(p \leq 0.05)$; ns $=$ non-significant $(p>0.05)$. contents in leaves were reduced by increasing the lime doses, and the leaf $\mathrm{P}$ contents increased linearly with increases in phosphate fertilizer (Table 6).

Table 2 - Soil levels of $\mathrm{K}, \mathrm{P}, \mathrm{Ca}$ and $\mathrm{Mg}$ available in response to the application of increasing doses of phosphorous to the soil in 2018 and 2019.

\begin{tabular}{|c|c|c|c|c|}
\hline $\mathrm{P}_{2} \mathrm{O}_{5}$ & \multicolumn{4}{|c|}{ Nutrient content available in the soil $\left(\mathrm{mg} \mathrm{kg}^{-1}\right)$} \\
\hline $\mathrm{kg} \mathrm{ha}^{-1}$ & \multicolumn{2}{|c|}{$\mathrm{mg} \mathrm{kg}^{-1}$} & \multicolumn{2}{|c|}{$\mathrm{cmol}_{\mathrm{c}} \mathrm{kg}^{-1} \longrightarrow$} \\
\hline \multicolumn{5}{|c|}{2018} \\
\hline & K & $\mathrm{P}$ & $\mathrm{Ca}$ & $\mathrm{Mg}$ \\
\hline 0 & $51.58^{\text {ns }}$ & $12.62^{\star 1}$ & $1.75^{\mathrm{ns}}$ & $1.03^{\text {ns }}$ \\
\hline 83.3 & 48.50 & 19.84 & 1.70 & 0.99 \\
\hline 166.6 & 51.16 & 24.10 & 1.74 & 0.97 \\
\hline 250.0 & 47.83 & 31.60 & 1.86 & 1.05 \\
\hline CV (\%) & 13.88 & 18.98 & 8.82 & 10.01 \\
\hline \multicolumn{5}{|c|}{2019} \\
\hline & K & $\mathrm{P}$ & $\mathrm{Ca}$ & $\mathrm{Mg}$ \\
\hline 0 & $28.50^{\text {ns }}$ & $4.34^{* 2}$ & $1.11^{\text {ns }}$ & $0.97^{\text {ns }}$ \\
\hline 83.3 & 26.58 & 7.09 & 1.14 & 0.98 \\
\hline 166.6 & 29.50 & 11.53 & 1.18 & 0.95 \\
\hline 250.0 & 25.75 & 14.77 & 1.21 & 0.98 \\
\hline$\overline{C V}(\%)$ & 18.94 & 40.35 & 12.17 & 7.50 \\
\hline
\end{tabular}

${ }^{1} y=0.0734 x+12.861\left(R^{2}=0.9898\right) ;{ }^{2} y=0.0429 x+4.0739\left(R^{2}=0.9926\right) ;$ $\mathrm{CV}=$ coefficient of variation; ${ }^{*}$ Significant $(p \leq 0.05) ; \mathrm{ns}=$ non-significant $(p$ $>0.05$ )

Table 3 - Levels of Al, $\mathrm{pH}$ and organic matter (OM) in response to the application of increasing lime doses to the soil in 2018 and 2019.

\begin{tabular}{|c|c|c|c|c|c|c|}
\hline \multirow{2}{*}{$\begin{array}{l}\text { Lime } \\
\text { dose }\end{array}$} & \multicolumn{2}{|c|}{$\mathrm{Al}$} & \multicolumn{2}{|c|}{$\mathrm{pH}$} & \multicolumn{2}{|c|}{$\mathrm{OM}$} \\
\hline & 2018 & 2019 & 2018 & 2019 & 2018 & 2019 \\
\hline $\mathrm{Mg} \mathrm{ha}^{-1}$ & \multicolumn{2}{|c|}{$-\mathrm{cmol}_{\mathrm{c}} \mathrm{kg}^{-1}-$} & & & \multicolumn{2}{|c|}{$\%$} \\
\hline 0 & $0.41^{* 1}$ & $0.65^{* 2}$ & $4.45^{* 3}$ & $4.68^{* 4}$ & $1.45^{\text {ns }}$ & $1.34^{\mathrm{ns}}$ \\
\hline 1.5 & 0.07 & 0.32 & 4.89 & 4.94 & 1.40 & 1.42 \\
\hline 3.0 & 0.00 & 0.08 & 5.29 & 5.25 & 1.40 & 1.35 \\
\hline 4.5 & 0.00 & 0.00 & 5.64 & 5.54 & 1.46 & 1.45 \\
\hline CV (\%) & 109.53 & 39.34 & 4.44 & 5.57 & 18.31 & 14.67 \\
\hline
\end{tabular}

Table 4 - Levels of $\mathrm{Al}, \mathrm{pH}$ and organic matter (OM) in response to the application of increasing phosphorous doses to the soil in 2018 and 2019.

\begin{tabular}{|c|c|c|c|c|c|c|}
\hline \multirow{2}{*}{$\mathrm{P}_{2} \mathrm{O}_{5}$} & \multicolumn{2}{|c|}{$\mathrm{Al}$} & \multicolumn{2}{|c|}{$\mathrm{pH}$} & \multicolumn{2}{|c|}{$\mathrm{OM}$} \\
\hline & 2018 & 2019 & 2018 & 2019 & 2018 & 2019 \\
\hline $\mathrm{kg} \mathrm{ha}^{-1}$ & \multicolumn{2}{|c|}{$-\mathrm{cmol} \mathrm{kg}^{-1}$} & & & \multicolumn{2}{|c|}{$\%$} \\
\hline 0 & $0.14^{\text {ns }}$ & $0.26^{\mathrm{ns}}$ & $5.09^{\text {ns }}$ & $5.17^{\text {ns }}$ & $1.47^{\text {ns }}$ & $1.35^{\text {ns }}$ \\
\hline 83.3 & 0.13 & 0.28 & 5.05 & 5.0 & 1.39 & 1.40 \\
\hline 166.6 & 0.11 & 0.28 & 5.00 & 5.04 & 1.42 & 1.41 \\
\hline 250.0 & 0.10 & 0.22 & 5.12 & 5.09 & 1.43 & 1.38 \\
\hline CV (\%) & 41.24 & 31.18 & 3.63 & 3.48 & 11.08 & 13.31 \\
\hline
\end{tabular}

$\mathrm{CV}=$ coefficient of variation; $\mathrm{ns}=$ non-significant $(p>0.05)$. 
Table 5 - Leaf contents of N, P, K, Ca and Mg in strawberry guava (Psidium cattleyanum Sabine) in response to the application of different lime doses to the soil in 2018 and 2019.

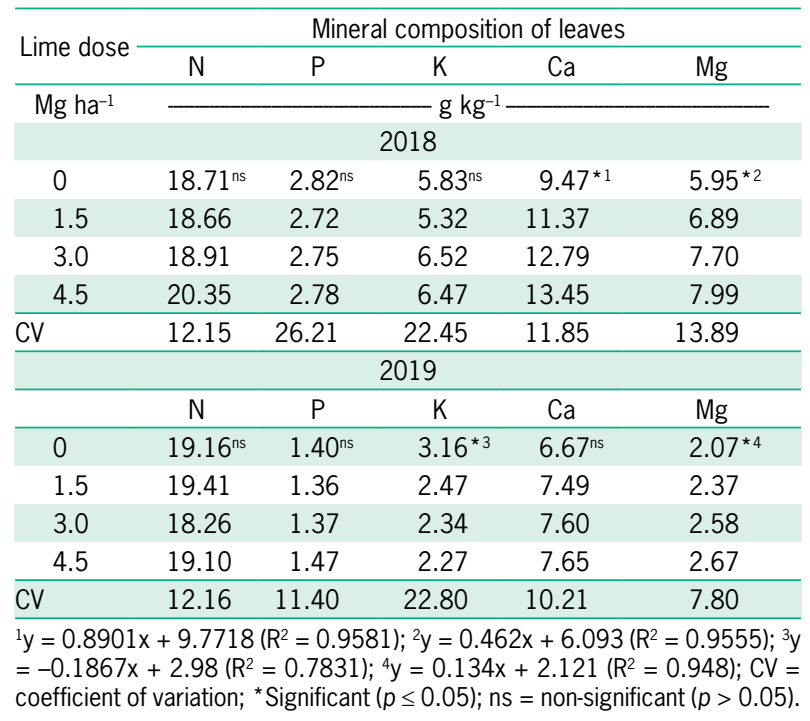

Table 6 - Leaf contents of N, P, K, Ca and Mg in strawberry guava (Psidium cattleyanum Sabine) in response to the application of different phosphorous doses to the soil in 2018 and 2019.

\begin{tabular}{cccccc}
\hline \multirow{2}{*}{$\mathrm{P}_{2} \mathrm{O}_{5}$} & \multicolumn{5}{c}{ Mineral composition of leaves } \\
\cline { 2 - 6 } $\mathrm{kg} \mathrm{ha}^{-1}$ & $\mathrm{~N}$ & $\mathrm{P}$ & $\mathrm{K}$ & $\mathrm{Ca}$ & $\mathrm{Mg}$ \\
\cline { 2 - 6 } & \multicolumn{5}{c}{$2018 \mathrm{~g} \mathrm{~kg}^{-1}$} \\
0 & $18.45^{\text {ns }}$ & $2.94^{\text {ns }}$ & $5.47^{\text {ns }}$ & $12.04^{\text {ns }}$ & $7.22^{\text {ns }}$ \\
83.3 & 18.97 & 2.84 & 5.77 & 11.40 & 6.98 \\
166.6 & 19.52 & 2.52 & 6.08 & 11.61 & 7.06 \\
250.0 & 19.69 & 2.77 & 6.81 & 12.03 & 7.28 \\
\hline $\mathrm{CV}$ & 10.20 & 17.82 & 21.13 & 14.78 & 10.80 \\
\hline \multicolumn{5}{c}{2019} \\
\hline \multicolumn{7}{c}{$\mathrm{P}$} & $\mathrm{K}$ & $\mathrm{Ca}$ & $\mathrm{Mg}$ \\
\hline 0 & $17.90^{\star 1}$ & $1.25^{\star 2}$ & $2.65^{\text {ns }}$ & $7.40^{\text {ns }}$ & $2.49^{\text {ns }}$ \\
\hline 83.3 & 18.38 & 1.37 & 2.61 & 7.24 & 2.32 \\
166.6 & 19.12 & 1.45 & 2.55 & 7.30 & 2.36 \\
250.0 & 20.65 & 1.53 & 2.41 & 7.47 & 2.52 \\
\hline $\mathrm{CV}$ & 10.41 & 14.09 & 14.40 & 9.32 & 9.97 \\
\hline
\end{tabular}

${ }^{1} y=0.0108 x+17.664\left(R^{2}=0.9333\right) ;{ }^{2} y=0.0011 x+1.262\left(R^{2}=0.988\right) ; C V$ $=$ coefficient of variation; ${ }^{*}$ Significant $(p \leq 0.05)$; ns $=$ non-significant $(p>0.05)$.

\section{Growth parameters and photosynthetic pigment indices}

As regards the growth parameters analyzed, there was no interaction between the lime and $\mathrm{P}$ doses, in the three years of evaluation, and no significant differences were detected for these variables in relation to the major effects of liming and phosphate fertilizer (Tables 7 and 8 ). The photosynthetic pigments were not affected by treatments in the first year of evaluation (2018); however, for the second year (2019), there was a linear reduction in CI, FI and NBI as the P doses increased (Table 9).
Table 7 - Plant growth parameters of strawberry guava (Psidium cattleyanum Sabine) in response to the application of different lime doses to the soil in 2017, 2018 and 2019.

\begin{tabular}{cccc}
\hline Lime dose & Trunk perimeter & Plant height & Canopy volume \\
\hline $\mathrm{Mg} \mathrm{ha}^{-1}$ & $\mathrm{~mm}$ & $\mathrm{~cm}$ & $\mathrm{~m}^{3}$ \\
\hline & \multicolumn{3}{c}{2017} \\
\hline 1.5 & $38.67^{\text {ns }}$ & $68.37^{\text {ns }}$ & $0.0768^{\text {ns }}$ \\
3.0 & 42.32 & 72.37 & 0.0958 \\
\hline 4.5 & 41.09 & 67.54 & 0.0800 \\
\hline $\mathrm{CV}(\%)$ & 40.29 & 68.08 & 0.0808 \\
\hline & 13.96 & 14.39 & 45.78 \\
\hline 0 & $67.95^{\text {ns }}$ & 2018 \\
\hline 1.5 & 70.88 & $107.33^{\text {ns }}$ & $0.810^{\text {ns }}$ \\
\hline 3.0 & 71.49 & 112.16 & 0.895 \\
\hline 4.5 & 69.92 & 110.45 & 0.900 \\
\hline $\mathrm{CV}(\%)$ & 10.94 & 8.00 & 0.864 \\
\hline \multicolumn{4}{c}{41.29} \\
\hline 0 & $88.07^{\text {ns }}$ & $116.62^{\text {ns }}$ & $1.37^{\text {ns }}$ \\
\hline 1.5 & 86.08 & 118.16 & 1.46 \\
\hline 3.0 & 91.12 & 120.79 & 1.45 \\
\hline 4.5 & 90.31 & 118.58 & 1.47 \\
\hline CV (\%) & 17.22 & 10.81 & 39.86 \\
\hline
\end{tabular}

$\mathrm{CV}=$ coefficient of variation; $\mathrm{ns}=$ non-significant at $p \leq 0.05$.

Table 8 - Growth parameters of strawberry guava (Psidium cattleyanum Sabine) in response to the application of different phosphorous doses to the soil in 2017, 2018 and 2019.

\begin{tabular}{|c|c|c|c|}
\hline $\mathrm{P}_{2} \mathrm{O}_{5}$ & Trunk perimeter & Plant height & Canopy volume \\
\hline $\mathrm{kg} \mathrm{ha}^{-1}$ & $\mathrm{~mm}$ & $\mathrm{~cm}$ & $\mathrm{~m}^{3}$ \\
\hline \multicolumn{4}{|c|}{2017} \\
\hline 0 & $41.09^{\text {ns }}$ & $68.54^{\text {ns }}$ & $0.0816^{\text {ns }}$ \\
\hline 83.3 & 39.35 & 69.95 & 0.0816 \\
\hline 166.6 & 41.65 & 70.00 & 0.0966 \\
\hline 250.0 & 40.29 & 67.87 & 0.0736 \\
\hline CV (\%) & 11.24 & 5.09 & 36.46 \\
\hline \multicolumn{4}{|c|}{2018} \\
\hline 0 & $71.96^{\mathrm{ns}}$ & $109.87^{\text {ns }}$ & $0.931^{\mathrm{ns}}$ \\
\hline 83.3 & 68.89 & 110.50 & 0.850 \\
\hline 166.6 & 70.82 & 112.58 & 0.894 \\
\hline 250.0 & 68.57 & 107.29 & 0.794 \\
\hline CV (\%) & 9.67 & 6.18 & 28.67 \\
\hline \multicolumn{4}{|c|}{2019} \\
\hline 0 & $92.31^{\text {ns }}$ & $120.70^{\text {ns }}$ & $1.66^{\mathrm{ns}}$ \\
\hline 83.3 & 89.13 & 116.25 & 1.33 \\
\hline 166.6 & 90.58 & 119.54 & 1.43 \\
\hline 250.0 & 83.58 & 117.66 & 1.33 \\
\hline CV (\%) & 11.05 & 5.54 & 27.38 \\
\hline
\end{tabular}

$\mathrm{CV}=$ coefficient of variation; $\mathrm{ns}=$ non-significant $(p>0.05)$.

\section{Mycorrhizal colonization}

In the strawberry guava roots, intra-radicular hypha, vesicles and arbuscules, typical structures of arbuscular mycorrhizae were observed. The liming presented no effect on the colonization rate of the root cortex and 
the arbuscule content in the mycorrhizal fraction. However, these variables became distinct in response to the phosphate fertilization (Figures 1,2 and 3), such as that in the treatments without $\mathrm{P}$ and the lowest level of nutrient correction was observed with the highest rates of mycorrhizal colonization and presence of arbuscules.

\section{Discussion}

The increase in $\mathrm{Ca}$ and $\mathrm{Mg}$ content in the soil justifies the advantage of the application of dolomitic lime, which has both nutrients in its composition, increasing their concentration in the soil and, consequently, the availability to plants (Masud et al., 2020). However, Ca soil content, even with the highest lime dose used, failed to reach high contents, i.e., higher than $4.0 \mathrm{cmol}_{\mathrm{c}}$ $\mathrm{kg}^{-1}$, according to suggested recommendations for the states of Rio Grande do Sul and Santa Catarina (CQFS-

Table 9 - Photosynthetic Pigment Index in strawberry guava (Psidium cattleyanum Sabine) in response to the application of different lime doses and phosphorous doses to the soil in 2018 and 2019 .

\begin{tabular}{|c|c|c|c|c|c|c|}
\hline \multirow{2}{*}{$\begin{array}{l}\text { Lime dose } \\
\left(\mathrm{Mg} \mathrm{ha}^{-1}\right)\end{array}$} & \multicolumn{2}{|c|}{ Chlorophyll Index } & \multicolumn{2}{|c|}{ Flavonoid Index } & \multicolumn{2}{|c|}{ Nitrogen Balance } \\
\hline & 2018 & 2019 & 2018 & 2019 & 2018 & 2019 \\
\hline 0 & $48.97^{\text {ns }}$ & 46.3 & & 1.8 & $5.31^{\mathrm{ns}}$ & $24.93^{\text {ns }}$ \\
\hline & & & & & 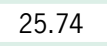 & 23.62 \\
\hline & & & & 1. & 5.77 & 24.35 \\
\hline 4. & 5 & 45 & & 1.8 & 26 & 24.77 \\
\hline$(\%)$ & 49 & 9.00 & 4.70 & 4.29 & 9.11 & 11.02 \\
\hline \multirow{2}{*}{$\begin{array}{c}\mathrm{P}_{2} \mathrm{O}_{5} \\
\left(\mathrm{~kg} \mathrm{ha}^{-1}\right)\end{array}$} & \multicolumn{2}{|c|}{ Chlorophyll Index } & \multicolumn{2}{|c|}{ Flavonoid Index } & \multicolumn{2}{|c|}{ Nitrogen Balance } \\
\hline & 2018 & 20 & 20 & 20 & 20 & 2019 \\
\hline 0 & $52.78^{\text {ns }}$ & $48.18^{* 1}$ & $2.01^{\mathrm{ns}}$ & $1.91 * 2$ & $26.32^{\mathrm{ns}}$ & $25.17^{* 3}$ \\
\hline 83. & 50.38 & 46.84 & 1.96 & 1.86 & 25.62 & 25.28 \\
\hline 166.6 & 51.76 & 43. & 1 & 18 & 26.51 & 24.08 \\
\hline 250.0 & 50.79 & 42.32 & 1.94 & 1.83 & 26.35 & 23.14 \\
\hline CV (\%) & 9.49 & 6.56 & 4.90 & 3.00 & 9.17 & 7.84 \\
\hline
\end{tabular}

${ }^{1} y=-0.0245 x+48.396\left(R^{2}=0.9817\right) ;{ }^{2} y=-0.0003 x+1.898\left(R^{2}=\right.$ $0.8524) ;{ }^{3} y=-0.0087 x+25.511\left(R^{2}=0.8696\right) ; C V=$ coefficient of variation; ${ }^{*}$ Significant $(p \leq 0.05) ; n s=$ non-significant $(p>0.05)$.

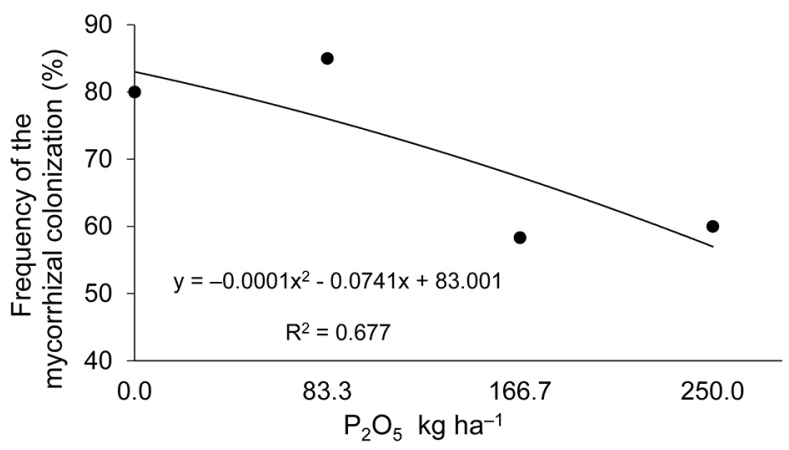

Figure 1 - Frequency of mycorrhizal colonization in the mycorrhizae fraction (\%), in response to the application of increasing doses of $P$ to the soil. Assessment performed in 2018, $p<0.05$.

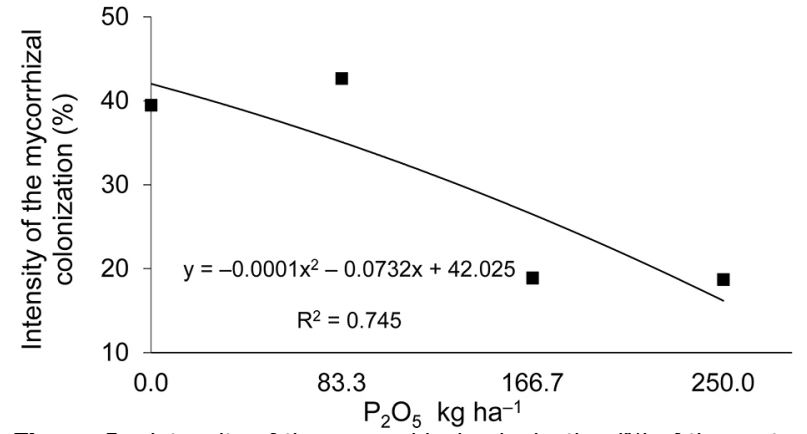

Figure 2 - Intensity of the mycorrhizal colonization (\%) of the roots, in response to the application of increasing doses of $P$ to the soil. Assessment performed in 2018, $p<0.05$.

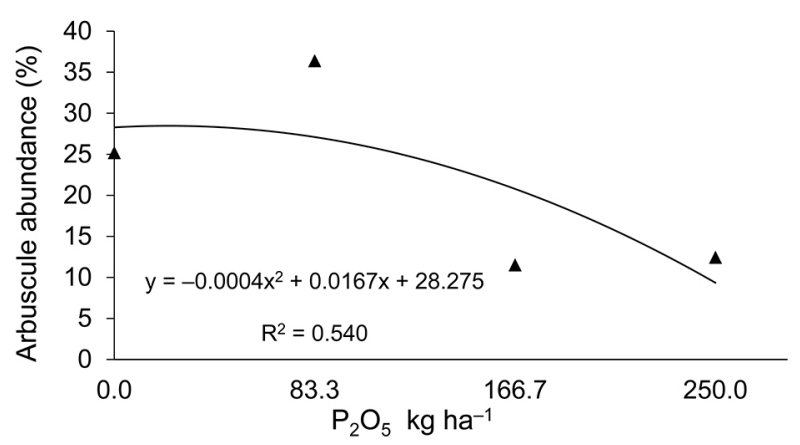

Figure 3 - Arbuscule abundance in the mycorrhizal fraction (\%) of the roots, in response to the application of increasing doses of $P$ to the soil. Assessment performed in 2018, $p<0.05$.

RS/SC, 2016). Determining Ca concentration in the soil is indicative of the growth potential of fruit plant root systems, especially in the orchard setting and formation. This positive lime effect on the leaf mineral composition is known due to Ca uptake occurring only in the youngest and non-suberized roots (Marschner, 2012), requiring continuous nutrient uptake to ensure the adequate development of plant meristematic regions (Tagliavini and Scandellari, 2013; Taiz et al., 2014). Soil $\mathrm{Mg}$ contents in the soil reached superior values at the critical level (above $1.0 \mathrm{cmol}_{\mathrm{c}} \mathrm{kg}^{-1}$ ), considered sufficient for adequate plant development (CQFS-RS/SC 2016). In addition to the increase in $\mathrm{Ca}$ and $\mathrm{Mg}$ availability to root uptake, lime application neutralizes acidity, endowing plants with a larger soil volume exploration capacity, and facilitating plant nutrient uptake (Nava et al., 2016).

Although phosphate fertilizer increased the soil $\mathrm{P}$ content, there were no differences in the $\mathrm{P}$ mineral content in strawberry guava leaves in the first year of leaf evaluation (Tables 1 and 3). One of the factors which can be associated with the absence of strawberry guava responses to phosphate fertilizer was the higher association between the roots and the arbuscular mycorrhizal fungi (AMF) (Figures 1,2 and 3). When the $\mathrm{P}$ soil levels were low, mycorrhizal contributed to the increase in $\mathrm{P}$ uptake through the larger soil volume 
explored by the extra-radicular hyphae, capable of uptaking nutrient in a more efficient way than the root structures (Smith et al., 2011; Marschner, 2012; Smith and Smith, 2012; Nava et al., 2016; Sawers et al., 2017). For the second year of evaluation, a difference in $\mathrm{P}$ leaf content emerged when the nutrient levels were low; however, it did not affect plant growth. These results indicate that in similar soils, even if soil $\mathrm{P}$ is ranked as "low", it is not a limiting factor for strawberry guava growth, indicating a possible role for mycorrhizal formation in the increase of $\mathrm{P}$ uptake and availability for plant metabolism during the growth period. Other characteristics can also contribute to the low response of fruit plants to phosphate fertilizer such as the lower extraction of this nutrient when compared to other macronutrients (Neilsen et al., 2008). Additionally, these plants have more time for nutrient uptake, favoring the storage of nutrients (Nava et al., 2016; Boutaj et al., 2020; Hassena et al., 2020).

It is important to point out that, even though strawberry guava did not present a growth positive response to the increase in soil $\mathrm{P}$ content, in the present study, the plants were evaluated only in the growth phase, during the first three years after the orchard had been planted. Thus, it is possible that higher $\mathrm{P}$ availability can influence growth during the plant yielding phase, which will be evaluated in later years.

The correlation between $\mathrm{Ca}$ content $(0.988$ and 0.980 ) and $\mathrm{Mg}$ (0.988 and 0.991) available in the soil with leaf nutrient concentration shows that strawberry guava has uptake capability for higher amounts of these nutrients as their soil content increases. Even in the absence of response in terms of plant growth, fruit quality can be positively affected in subsequent years, according to the results found by Nava et al. (2016), in feijoa (Acca sellowiana) plants. Ca, available by liming, is taken up from the soil solution and transported to the shoots through the xylem, in demand in higher amounts in the plant meristematic regions (Marschner, 2012; Kumar et al., 2015; Taiz et al., 2014). In acid soils, in general, there is low availability of this nutrient. Therefore, Ca content in the fruit may not reach adequate levels, which can affect both quality and storage ability. The low $\mathrm{Ca}$ content in fruit increases membrane permeability and reduces pulp firmness, allowing solute diffusion in these tissues (Aghdam et al., 2012; Yahia et al., 2019). Furthermore, the application, distribution and incorporation of acid correctors in pre-planting plays a fundamental role in perennial crops, such as strawberry guava, taking into account that in this phase there is higher liming efficiency (Souza et al., 2009).

Plant growth improvement in acid soils is due not only to the addition of basic cations ( $\mathrm{Ca}$ and $\mathrm{Mg}$ ), but to the reduction of Al toxicity (Brown et al., 2008; Abd El-Halim and Omae, 2019). Therefore, even at $\mathrm{pH}$ 4.45 (zero lime dose) strawberry guava did not have its growth affected, indicating that, although the highest lime dose had raised the soil $\mathrm{pH}$ to 5.65 , this species does not need such a high $\mathrm{pH}$ during the growth phase provided that the soil Al contents are not high. Other reports on effects of lime on guava (Psidium guajava L.) (Souza et al., 2009) and feijoa (Acca sellowiana) growth (Nava et al., 2016), have described responses that are different from those found here; they have observed an increase in plant growth in response to liming. However, the exchangeable $\mathrm{Al}$ levels in these studies were higher than the one observed here (1.1 and $5.5 \mathrm{cmol}_{\mathrm{c}} \mathrm{kg}^{-1}$, respectively).

The reduction in $\mathrm{K}$ uptake by the plants, as a function of lime levels, can be a consequence of the increase in the cation exchange capability, due to the release of charges taken by $\mathrm{H}^{+}$and by $\mathrm{Al}^{3+}$ electrostatically adsorbed to the soil negative charges. Thus, part of $\mathrm{k}$ could have migrated to the negative charges formed by liming, reducing the $\mathrm{K}$ contents in the soil solution and, consequently, reducing $\mathrm{K}$ uptake by plants (Ernani, 2016).

The reduction in $\mathrm{CI}, \mathrm{FI}$ and $\mathrm{NBI}$, in the second year, supports the increase in $\mathrm{N}$ leaf content as a function of increases in $\mathrm{P}$ doses, since $\mathrm{N}$ depletion induces the leaf flavonoid content (Stewart et al., 2001; Mittelstraß et al., 2006; Abdallah et al., 2019). The scarcity of P may have reduced $\mathrm{N}$ uptake and assimilation, due to the high energy demand (ATP) required for amino acid formation (Taiz et al., 2014) and, consequently its influence over NBI, which reflects the CI/FI ratio.

Flavonoids represent the largest class of phenolic compounds, have antioxidant properties and its function in plants is related to stress situations (Taiz et al., 2014). Therefore, high acidity and low nutrient availability, as with $\mathrm{P}$, can affect flavonoid production (Kovácyc and Klejdus, 2014) Whatsmore, it is known that phenolic compounds are part of root exsudates that act as molecular signs in the establishment of symbiosis between the roots and AMFs, promoting a higher rate of mycorrhizal colonization (Siqueira et al., 1991; Smith et al., 2011). Marschner (2012) reports that mycorrhizal intensity is proportional to $\mathrm{P}$ availability to the host plant in the soil. Therefore, when there is P deficiency, the plant tends to depend much more on $\mathrm{P}$ uptake by mycorrhizae, which stimulates the association with FMAs, contributes to the improvement of the nutritional status of the host plant, and agrees with the results found herein.

\section{Conclusions}

Strawberry guava shows adequate initial growth, even in acid soils, providing that exchangeable $\mathrm{Al}$ contents are not high. Liming increases the $\mathrm{Ca}$ and $\mathrm{Mg}$ contents in the soil, as well as in the strawberry guava leaves. However, there is no positive influence on initial plant growth.

Phosphate fertilization does not influence strawberry guava growth up to the third year. Higher mycorrhizal colonization under conditions of limiting $\mathrm{P}$ in the soil indicates that the symbiosis contributes to the uptake and nutrition of $\mathrm{P}$ in strawberry guava. 


\section{Acknowledgments}

To the Coordination for the Improvement of Higher Level Personnel (CAPES) - Financing Code 001, to the Brazilian National Council for Scientific and Technological Development (CNPq) for the scholarship awarded, to the Postgraduate Program in Agronomy FAEM/UFPel, to Federal University of Pelotas - UFPel and to Embrapa Temperate Agriculture for the provision of financial support and facilities.

\section{Authors' Contributions}

Conceptualization: Benati, J.A.; Navroski, R.; Barreto, C.F.; Fischer, L.O.; Herter, F.G. Data acquisition: Benati, J.A.; Nava, G.; Franzon R.C.; Herter, F.G.; Dalla Costa, M. Data analysis: Benati, J.A.; Navroski, R.; Barreto, C.F.; Fischer, L.O.; Nava, G.; Dalla Costa, M. Design of methodology: Nava, G.; Franzon, R.C. Writing and editing: Benati, J.A.; Nava, G.; Dalla Costa, M.; Franzon, R.C.

\section{References}

Abd El-Halim, A.A.; Omae, H. 2019. Performance assessment of nanoparticulate lime to accelerate the downward movement of calcium in acid soil. Soil Use and Management 35: 683-690. https://doi.org/10.1111/ sum. 12525

Abdallah, F.B.; Philippe, W.; Goffart, J.P. 2019. Comparison of optical indicators for potato crop nitrogen status assessment including novel approaches based on leaf fluorescence and flavonoid content. Journal of Plant Nutrition 41: 27052728. https://doi.org/10.1080/01904167.2018.1510514

Aghdam, M.S.; Hassanpouraghdam, M.B.; Paliyath, G.; Farmani, B. 2012. The language of calcium in postharvest life of fruits, vegetables and flowers. Scientia Horticulturae 144: 102-115. https://doi.org/10.1016/j.scienta.2012.07.007

Alvares, C.A.; Stape, J.L.; Sentelhas, P.C.; Moraes, G.; Leonardo, J.; Sparovek, G. 2013. Köppen's climate classification map for Brazil. Meteorologische Zeitschrift 22: 711-728. https:// doi.org/10.1127/0941-2948/2013/0507

Boutaj, H.; Meddich, A.; Chakhchar, A.; Wahbi, S.; El AlaouiTalibi, Z.; Douira, A.; El Modafar, C. 2020. Arbuscular mycorrhizal fungi improve mineral nutrition and tolerance of olive tree to Verticillium wilt. Archives of Phytopathology and Plant Protection 53: 673-689. https://doi.org/10.1080/0 3235408.2020.1792603

Brown, T.T.2008. Lime effects on soil acidity, crop yield, and aluminum chemistry in direct-seeded cropping systems. Soil Science Society of America Journal 72: 634640. https://dx.doi.org/10.2136/sssaj2007.0061

Comissão de Química e Fertilidade do Solo - RS/SC [CQFSRS/SC]. 2016. Lime and Fertilizer Manual for the States of Rio Grande do Sul and Santa Catarina = Manual de Calagem e Adubação para os Estados do Rio Grande do Sul e Santa Catarina. Sociedade Brasileira de Ciência do Solo, Porto Alegre, RS, Brazil (in Portuguese).
Denardin, C.C.; Hirsch, G.E.; Rocha, R.F.; Vizzotto, M.; Henriques, A.T.; Moreira, J.C.; Emanuelli, T. 2015. Antioxidant capacity and bioactive compounds of four Brazilian native fruits. Journal of Food and Drug Analysis 23: 387-398. https://doi.org/10.1016/j.jfda.2015.01.006

Ernani, P.R. 2016. Soil Chemistry and Nutrient Availability = Química do Solo e Disponibilidade de Nutrientes. The Author, Lages, SC, Brazil (in Portuguese).

Ferreira, D.F. 2014. Sisvar: a guide for its bootstrap procedures in multiple 327 comparisons. Ciência e Agrotecnologia 38: 109-112. https://doi.org/10.1590/S1413-70542014000200001

Gianinazzi, S.; Gollotte, A.; Binet, M.N.; van Tuinen, D.; Redecker, D.; Wipf, D. 2010. Agroecology: the key role of arbuscular mycorrhizas in ecosystem services. Mycorrhiza 20: 519-530. https://doi.org/10.1007/ s00572-010-0333-3

Hassena, A.B.; Zouari, M.; Trabelsi, L.; Decou, R.; Amar, F.B.; Chaari, A.; Soua, N., Labrouse, P.; Khabou, W.; Zouari, N. 2020. Potential effects of arbuscular mycorrhizal fungi in mitigating the salinity of treated wastewater in young olive plants (Olea europaea L. cv. Chetoui). Agricultural Water Management 245: 106635. https://doi.org/10.1016/j. agwat.2020.106635

Koske, R.E.; Gemma, J.N. 1989. A modified procedure for staining roots to detect VA mycorrhizas. Mycological Research 92: 486-488.

Kumar, A.; Singh, U.M.; Manohar, M.; Gaur, V.S. 2015. Calcium transport from source to sink: understanding the mechanism(s) of acquisition, translocation, and accumulation for crop biofortification. Acta Physiologiae Plantarum 37: 1722. https://doi.org/10.1007/s11738-014-1722-6

Marschner, H. 2012. Mineral Nutrition of Higher Plants. Academic Press, London, UK.

Marschner, H.; Dell, B. 1994. Nutrient uptake in mycorrhizal symbiosis. Plant and Soil 159: 89-102. https://doi. org/10.1007/BF00000098

Masud, M.M.; Abdulaha-Al Baquy, M.; Akhter, S.; Sen, R.; Barman, A.; Khatun, M.R. 2020. Liming effects of poultry litter derived biochar on soil acidity amelioration and maize growth. Ecotoxicology and Environmental Safety 202: 110865. https://doi.org/10.1016/j.ecoenv.2020.110865

Medina, A.L.; Haas, L.I.R.; Chaves, F.C.; Salvador, M.; Zambiazi, R.C.; Silva, W.P.; Nora, L.; Rombaldi, C.V. 2011. Araçá (Psidium cattleianum Sabine) fruit extracts with antioxidant and antimicrobial activities and antiproliferative effect on human cancer cells. Food Chemistry 128: 916-922. https://doi.org/10.1016/j.foodchem.2011.03.119

Mittelstraß, K.; Treutter, D.; Pleßl, M.; Heller, W.; Elstner, E.F.; Heiser, I. 2006. Modification of primary and secondary metabolism of potato plants by nitrogen application differentially affects resistance to Phytophthora infestans and Alternaria solani. Plant Biology 8: 653-661. https://doi. org/10.1055/s-2006-924085

Nava, G.; Santos, K.L.D.; Costa, M.D.; Ciotta, M.N. 2016. Growth, mineral composition, fruit yield, and mycorrhizal colonization of feijoa in response to lime and phosphorus application. Pesquisa Agropecuária Brasileira 51: 942-949. http://dx.doi.org/10.1590/S0100-204X2016000800006 
Neilsen, G.H.; Neilsen, D.; Toivonen, P.; Herbert, L. 2008. Annual bloom-time phosphorus fertigation affects soil phosphorus, apple tree phosphorus nutrition, yield, and fruit quality. HortScience 43: 885-890. https://doi.org/10.21273/ HORTSCI.43.3.885

Patel, S. 2012. Exotic tropical plant Psidium cattleianum: a review on prospects and threats. Reviews in Environmental Science and Bio/Technology 11: 243-248 https://doi.org/10.1007/ s11157-012-9269-8.

Qaswar, M.; Dongchu, L.; Huang Jing, H.; Tianfu, H.; Ahmed W.; Dongchu, L.; Jing, H.; Tianfu, H.; Ahmed W.; Abbas, M.; Lu, Z.; Jiangxue, D.; Khan, Z.H.; Ullah, S.; Huimin, Z.; Boren, $\mathrm{W}$. 2020. Interaction of liming and long-term fertilization increased crop yield and phosphorus use efficiency (PUE) through mediating exchangeable cations in acidic soil under wheat-maize cropping system. Scientific Reports 10: 19828. https://doi.org/10.1038/s41598-020-76892-8

Ribeiro, A.B.; Chisté, R.C.; Freitas, M.; Silva, A.F.; Visentainer, J.V.; Fernandes, E. 2014. Psidium cattleianum fruit extracts are efficient in vitro scavengers of physiologically relevant reactive oxygen and nitrogen species. Food Chemistry 165: 140-148. https://doi.org/10.1016/j.foodchem.2014.05.079

Sawers, R.J.; Svane, S.F.; Quan, C.; Grønlund, M.; Wozniak, B.; Gebreselassie, M.N.; González-Muñoz, E.; Chávez Montes, R.A.; Baxter, I.; Goudet, J.; Jakobsen, I.; Paszkowski, U. 2017. Phosphorus acquisition efficiency in arbuscular mycorrhizal maize is correlated with the abundance of root-external hyphae and the accumulation of transcripts encoding PHT1 phosphate transporters. New Phytologist 214: 632-643. https:// doi.org/10.1111/nph.14403

Siqueira, J.O.; Safir, G.R.; Nair, M.G. 1991. Stimulation of vesicular-arbuscular mycorrhiza formation and growth of white clover by flavonoid compounds. New Phytologist 118: 87-93. https://doi.org/10.1111/j.1469-8137.1991.tb00568.x

Smith, S.E.; Read, D.J. 2010. Mycorrhizal Symbiosis. Academic Press, London, UK.

Smith, S.E.; Smith, F.A. 2012. Fresh perspectives on the roles of arbuscular mycorrhizal fungi in plant nutrition and growth. Mycologia 104: 1-13. https://doi.org/10.3852/11-229

Smith, S.E.; Jakobsen, I.; Grønlund, M.; Smith, F.A. 2011. Roles of arbuscular mycorrhizas in plant phosphorus nutrition: interactions between pathways of phosphorus uptake in arbuscular mycorrhizal roots have important implications for understanding and manipulating plant phosphorus acquisition. Plant Physiology 156: 1050-1057. https://doi. org/10.1104/pp.111.174581
Soil Survey Staff. 2014. Keys to Soil Taxonomy. USDA-Natural Resources Conservation Service, Washington, DC, USA.

Souza, H.A.; Natale, W.; Prado, R.M.; Rozane, D.E.; Romualdo, L.M.; Hernandes, A. 2009. Liming effect on guava growth. Revista Ceres 56: 336-341 (in Portuguese, with abstract in English). https://www.redalyc.org/pdf/3052/305226745016. pdf

Stewart, A.J.; Chapman, W.; Jenkins, G.I.; Graham, I.; Martin, T.; Crozier, A. 2001. The effect of nitrogen and phosphorus deficiency on flavonol accumulation in plant tissues. Plant, Cell and Environment 24: 1189-97. https://doi.org/10.1046/ j.1365-3040.2001.00768.x

Tagliavini, M.; Scandellari, F. 2013. Methodologies and concepts in the study of nutrient uptake requirements and partitioning in fruit trees. Acta Horticulturae 984: 47-56. https://doi. org/10.17660/ActaHortic.2013.984.3

Taiz, L.; Zeiger, E.; Møller, I.M.; Murphy, A. 2014. Plant Physiology and Development. Sinauer, Sunderland, MA, USA.

Tedesco, M.J.; Gianello, C.; Bissani, C.; Bohnen, H.; Volkweiss, S.J. 1995. Analysis of Soil, Plants and other Materials = Análise de Solo, Plantas e outros Materiais. Universidade Federal do Rio Grande do Sul, Porto Alegre, RS, Brazil (in Portuguese).

Vierheilig, H.; Coughlan, A.P.; Wyss, U.R.S.; Piché, Y. 1998. Ink and vinegar, a simple staining technique for arbuscularmycorrhizal fungi. Applied and Environmental Microbiology 64: 5004-5007. https://doi.org/10.1128/AEM.64.12.50045007.1998

Wang, B.; Qiu, Y.L. 2006. Phylogenetic distribution and evolution of mycorrhizas in land plants. Mycorrhiza 16: 299-363. https:// doi.org/10.1007/s00572-005-0033-6

Yahia, E.M.; Gardea-Béjar, A.; Ornelas-Paz, J.J.; Maya-Meraz, I.O.; Rodríguez-Roque, M.J.; Rios-Velasco, C.; Ornelas-Paz, J.; SalasMarina, M.A. 2019. Preharvest factors affecting postharvest quality. Postharvest Technology of Perishable Horticultural Commodities 10: 99-128. https://doi.org/10.1016/B978-0-12813276-0.00004-3 